\title{
Контроль над грузами во Владивостоке в контексте политической борьбы летом 1918 г.
}

Владивостокский порт - важнейшая часть транспортной инфраструктуры региона - в отдельные периоды истории играл особую роль в обеспечении обороноспособности государства. Однако эта сторона его деятельности, как, впрочем, и история порта в целом, пока находится лишь в самом начале изучения. Пожалуй, наиболее интенсивно в последнее время изучается функционирование порта в период Первой мировой войны. Исследователи характеризуют эти годы как время интенсивного развития Владивостокского порта, превратившегося в ключевой пункт в системе транспортных коммуникаций Российской империи и союзных государств $[1 ; 2 ; 3]$. За годы войны его грузооборот вырос почти в два раза. Однако, несмотря на усилия по техническому переоснащению порта, в течение всей войны так и не удалось наладить оперативный вывоз военного имущества $[1, \mathbf{c . ~ 5 7 ]}$. Не менее сложным было положение с частными грузами. На 21 июня 1918 г. на таможенных складах Владивостока числилось более 10 млн. пудов разных грузов (РГИА ДВ. Ф. Р-722. Оп. 1. Д. 13. Л. 1). К осени положение еще более осложнилась: на 10 сентября 1918 г. во Владивостоке скопилось уже более 35,5 млн. пудов. Лишь треть из них хранилась на таможенных складах (РГИА ДВ. Ф. Р-722. Оп. 1. Д. 7. Л. 28 об.). Газета "New York Times" так описывала эту ситуацию: "Во время войны были построены десятки огромных складов для хранения портящихся товаров, когда же они оказались переполнены, оказалось, что строить новые с той же скоростью, с какой в город поступают грузы, не удается, и теперь всё, что прибывает в порт - от тюков с бязью до деталей грузовиков, сбрасывают на землю и укрывают брезентом" [4, с. 105].

Всё сказанное выше объясняет, почему одной из наиболее острых во Владивостоке была проблема контроля над вывозом грузов. Варианты её решения с помощью разнообразных комиссий по учету, распределению, использованию грузов предпринимались на протяжении всей Гражданской войны. Каждое правительство, хотя бы ненадолго закреплявшееся во Владивостоке, пыталось "снять проблему", создавая специальные комиссии [5, с. 81]. Иногда эти попытки выливались в настоящее противостояние.

Попытаемся показать такое противостояние на примере одного из первых эпизодов борьбы за контроль над грузами во Владивостоке летом 1918 г. Основными участниками конфликта стали Приморская областная земская управа и таможенное ведомство в лице Владивостокского таможенного инспектора и управляющего Владивостокской таможни. Конфликт, в основе которого лежали чисто экономические проблемы, развивался на фоно острого политического противостояния "двух соперничавших, но равно безвластных дальневосточных правительств" - Делового кабинета Д. Л. Хорвата и Временного правительства автономной Сибири А. И. Лаврова и П. Я. Дербера [7, с. 21]. При этом таможенное ведомство находилось всецело на стороне Хорвата, учредившего в составе Делового кабинета Управление таможенными сборами "для общего управления таможенными установлениями и объединения их деятельности" (РГИА ДВ. Ф. Р-722. Оп. 1. Д. 25. Л. 12). В фреврале 1918 г. на должность исполняющего дела Владивостокского таможенного инспектора был назначен П.П. Маевский, занимавший до этого должность помощника Хабаровского таможенного инспектора.

Начало противостоянию положили почти одновременные попытки Приморской областной земской управы и таможенного ведомства упорядочить

(C) Беляева Н. А., 2021

БЕЛЯЕВА Наталья Анатольевна, д-р ист. наук, профессор департамента истории и археологии Дальневосточного федерального университета (2. Владивосток). E-mail: minava204@rambler.ru 
ввоз и вывоз грузов. Проблемы эта была не нова. Её пытались решить Владивостокский совет и советское правительство, в преддверии интервенции предпринявшее попытку не только провести учет огромного количества скопившихся во Владивостоке грузов, но и наладить их использование в интересах советской России [6, с. 134].

29 июня 1918 г., в день выступления чехословаков во Владивостоке, вернувшая себе властные полномочия Приморская областная земская управа создала комиссию по ввозу и вывозу в составе трёх человек. Спустя 10 дней (8 августа), при Владивостокской таможне начала работу подобная комиссия под председательством её управляющего И.К. Ковалевского. Кроме двух ревизоров таможни к участию в ней были приглашены представители биржевого комитета, "торгово-промышленного класса" и областного управления в лице Приморской областной земской управы. Впрочем, последняя приглашение проигнорировала (РГИА ДВ. Ф. Р-722. Оп. 1. Д. 6. Л. 2). Необходимо отметить, что таможенные чиновники в данном случае не изобретали ничего нового, а опирались на опыт работы межведомственной комиссии при департаменте таможенных сборов в Петрограде.

О предстоящем начале работы "таможенной комиссии" население Владивостока было уведомлено еще 2 августа, когда в газете "Голос Приморья" было опубликовано соответствующее объявление от имени Владивостокского таможенного инспектора. Сам текст объявления, как и последующие разъяснения таможенными чиновниками сути их расхождений с "земской комиссией" говорят о том, что в данном случае ведомство выступало с позиций защиты "интересов казённого управления". Понимая опасность дезориентации внешнеторговых фирм и частных предпринимателей в условиях существования двух параллельных структур, таможенный инспектор обращал внимание на произвольную трактовку "земской комиссией" таможенного законодательства и полное игнорирование ею сложившегося во Владивостокском порту за годы Первой мировой войны порядка таможенного оформления грузов (РГИА ДВ. Ф. 410. Оп. 2. Д. 236. Л. 40). Инспектор подчеркивал важность сохранения "неизменности порядка", при котором "никакие предметы не будут выпускаться Владивостокской таможней прежде, чем на это последует разрешение особой комиссии, учрежденной при таможне, под председательством управляющего ею". При этом для вывоза некоторых товаров требовалось ещё и санкция члена Делового кабинета по военным делам. Во избежание ошибок и "замедления с операциями" по всем возникающим вопросам предлагалось обращаться непосредственно к председателю комиссии - управляющему Владивостокской таможни И. К. Ковалевскому (РГИА ДВ. Ф. 410. Оп. 2. Д. 236. Л. 40-40 об.). Можно предположить, что именно упоминание в связи с контролем над грузами Делового кабинета дало толчок для перехода конфликта в острую фазу.

12 августа Приморская областная земская управа потребовала у управляющего Владивостокской таможней и таможенного инспектора объяснений и, не удовлетворившись ими, спустя два дня приняла постановление "Об устранении от должности и предании суду и. д. таможенного инспектора Владивостокского района Маевского" (РГИА ДВ. Ф. 410. Оп. 2. Д. 236. Л. 41-41 об.). Последующее развитие событий показывает, что к столь решительным действиям земцев побуждали вовсе не соображения "практической пользы", а политическое соперничество с Деловым кабинетом. Оценив провозглашение Хорвата Временным правителем как "акт преступного присвоения им не принадлежащей ему верховной власти", земцы объявили и действия поддержавшего Деловой кабинет таможенного инспектора ни больше, ни меньше как преступление по должности. Считая себя в данный момент единственным правомочным органом государственной власти на Дальнем Востоке, земская управа приняла решение: П.П. Маевского от должности отстранить и обратиться к прокурору для предания его суду; комиссию при Владивостокской таможне немедленно распустить; обязать таможню командировать своего представителя в образованную управой комиссию по ввозу и вывозу во Владивостокском порту. При этом таможенному ведомству предлагалось впредь "при разрешении всех вопросов по ввозу во Владивостокский порт и вывозу из него товаров... руководствоваться исключительно постановлениями соответствующей комиссии при областной земской управе" (РГИА ДВ. Ф. 410. 
Оп. 2. Д. 236. Л. 41-41об). 17 августа постановление было опубликовано в газете "Далёкая окраина", тем самым конфликт был перенесен в публичное пространство.

Дальнейшее развитие событий отражено в сохранившемся в фонде Управления Владивостокского таможенного инспекторства архивном деле "О вмешательстве земской областной управы в дела таможенного ведомства" [5]. Это название было дано в процессе таможенного делопроизводства, тогда как в описи фонда фогурирует другое, сформулированное архивистами: "Ревизия Приморской областной земской управы в ведомстве Владивостокского таможенного инспектора". Следует заметить, что первый вариант полностью отражает существо отложившихся в архивном деле документов, лишь незначительная часть которых посвящена собственно ревизии, а точнее неудавшейся попытке земской управы провести ревизию в управлении Владивостокского таможенного инспектора.

21 августа, опасаясь "замешательства", которое публикация постановления управы может вызвать в торговых кругах, П. П. Маевский в последний раз попытался объяснить земцам ошибочность их действий. Его доводы можно свести к нескольким. Первый: кроме земской управы в городе есть и другие государственные органы, в частности, таможня, которой дано "право казённого управления". Второй: деятельность таможни основана на соблюдении российских законов и в первую очередь Устава таможенного "под опасением ответственности по закону" запрещавшего вмешательство как военного, так и гражданского начальства в "непосредственные распоряжения по таможенной части" (РГИА ДВ. Ф. 410. Оп. 2. Д. 236. Л. 8). Наконец, третий: таможенное ведомство в силу действующего законодательства подчиняется не местной власти, а исключительно Министерству финансов и департаменту таможенных сборов, единственным аналогом которого в это время было учрежденное при Деловом кабинете управление таможенными сборами во главе с опытным таможенным чиновником С. Н. Латкиным, в своё время занимавшим должность начальника Приамурского таможенного округа. Именно поэтому вмешательство управы в дела ведомства инспектор счёл незаконным, а её распоряжения не подлежащими исполнению. Одновременно земцы были извещены о направлении на имя прокурора Владивостокского окружного суда жалобы на превышение полномочий руководителями управы (РГИА ДВ. Ф. Р-722. Оп. 1. Д. 25. Л. 12). Но к этому времени и сама управа направила прокурору представление об уголовном преследовании инспектора, обвинив его в должностном преступлении.

Та же мысль о недопустимости вмешательства местных властей в дела таможенного ведомства четко сформулирована в записке, направленной управляющим Владивостокской таможни И. К. Ковалевским в земскую управу 12 августа 1918 г., как раз накануне принятия ею постановления об отстранении таможенного инспектора. В документе, копия которого сохранилась также в делопроизводстве управления таможенного инспектора, подробно перечисляются все нормативные акты, принятые в период Первой мировой войны и действующие до сих пор в отношении ввоза и вывоза товаров. Как ранее инспектор, управляющий напомнил об особом статусе таможенных учреждений, относящихся к центральному управлению. В экстренных случаях по "принятому в таможенном ведомстве порядку, - подчёркивал он, - таможня в согласии с распоряжениями местного таможенного инспектора ...принимает на себя разрешение тех или иных дел, подлежащих ведению центральных учреждений Министерства финансов". Именно поэтому, во исполнение распоряжения Владивостокского инспектора, при таможне и была создана комиссия. Её деятельность, таким образом, базируется на нормах действующего законодательства. Выдержанная в спокойном деловом тоне, записка управляющего была последней попыткой разрешить сложившуюся ситуацию "к общей пользе" (РГИА ДВ. Ф. 410. Оп. 2. Д. 236. Л. 29-29 об.).

Как показывают документы, в дальнейшем развитии событий важную роль сыграли не только политические предпочтения, но и личные амбиции председателя Приморской областной земской управы А.С. Медведева. 23 августа была предпринята попытка провести ревизию в управлении таможенного инспектора. Однако прибывшая комиссия даже не была допущена в служебные помещения инспекторства. Тогда 29 августа по предписанию А.С. Медве- 
дева таможенный инспектор П. П. Маевский был арестован и препровожден в городскую тюрьму. Помещение управления было закрыто и опечатано. Все чиновники, в том числе и находившиеся там "по делам службы" управляющие таможенными заставами, были буквально выставлены на улицу.

Из-под ареста инспектор был освобожден через 3 часа, после решительного вмешательства прокурора Владивостокского окружного суда. Но это событие было расценено таможенными чиновниками - свидетелями ареста как вопиющее нарушение закона и создание помех в работе государственного учреждения (РГИА ДВ. Ф. 410. Оп. 2. Д. 236. Л. 36-36 об.). Отметим, что это была первая попытка силового давления на таможенные учреждения, которых в дальнейшем будет немало.

Таким образом, конфоликт перерос в открытое противостояние двух ведомств: традиционно воспринимавшей себя как часть государственного аппарата таможни и возвысившейся на волне револющии земской управы. Исподволь в него стали втягиваться и другие участники политического процесса. Редкое единодушие в оценке действий земцев проявили представители борющихся между собой политических течений. 29 августа немедленного освобождении Маевского, снятия печатей, наложенных ревизионной комиссией и приостановки самой ревизии потребовал министр внутренних дел Временного правительства автономной Сибири А. Е. Новоселов (РГИА ДВ. Ф. 410. Оп. 2. Д. 236. Л. 16). А 31 августа 1918 г. действия Приморской областной земской управы единогласно осудило собрание начальников правительственных учреждений и ведомств г. Владивостока под председательством профрессора Восточного института В. М. Мендрина. В особой резолюции собрание выразило негодование по поводу действий земской управы во главе с председателем и поддержало таможенного инспектора (РГИА ДВ. Ф. 410. Оп. 2. Д. 236. Л. 51).

Имел ли разгоревшийся конфликт под собой реальные основания и возможности завершиться в позитивном ключе? Ответ на этот вопрос был дан в октябре 1918 г. агентом торгового отдела Министерства снабжения и продовольствия Временного сибирского правительства П. Томиляковым, изучавшим ситуацию во Владивостоке по поручению министра. Свои выводы он сформулировал следующим образом: "Таким образом, одновременно существовало два органа: комиссия при таможне из знающих, опытных в своем деле людей, приносящих пользу государству и комиссия при земской управке (maк в тексте - Н.Б.) из трех человек, которая должна была быть мертворожденным учреждением. Земская управа до сих пор считает, что комиссия при ней существует, но трудно представить себе, в чем же заключается её фрункции при столь компетентном органе, как таковая же в таможне" (РГИА ДВ. Ф. Р-722. Оп. 1. Д. 6. Л. 2). Выход из создавшегося положения агент видел в создании новой (правительственной) комиссии, которая будет ведать ввозом и вывозом и работать в тесном контакте с таможней, либо в направлении своего представителя в уже существующую при таможне комиссию.

Примерно в это же время действия участников конфоликта получили правовую оценку. Прокурор Иркутской судебной палаты - высшей инстанции по отношению к Владивостокскому окружному суду - занял сторону таможенного ведомства. Дело в отношении таможенного инспектора, обвиняемого земской управой в преступлении по должности, было прекращено за отсутствием состава преступления. Действия же руководителей Приморской областной земской управы А. С. Медведева, А. Н. Каликанова, Б. Е. Сквирского, С. И. Афранасьева и А. А. Меньщикова были квалифицированы как "превышение власти, удержание чиновника от законного исполнения его обязанностей по службе под угрозами и действительным, вооруженным насилием" и переданы "на усмотрение" управляющего Приморской областью. 25 февраля 1919 г. поступившие из Иркутской судебной палаты документы были переданы прокурору Владивостокского окружного суда с просьбой дать делу "надлежащий ход" (РГИА ДВ. Ф. Р-534. Оп. 1. Д. 67. Л. 38 об.-39). К сожалению, на основании выявленных документов невозможно установить, было ли доведено до конца судебное разбирательство. С уверенностью можно лишь сказать, что межведомственный спор, осложненный разногласиями на политической почве, имел выраженную линию личного противостояния. Его прямым следствием стал арест обоих оппонентов управы после её прихода к 
власти в качестве Временного правительства Дальнего Востока. В феврале 1920 г. покинувший к тому времени службу в таможенном ведомстве и занимавший, по его словам, "скромную должность незначительного чиновника" П. П. Маевский был арестован Следственной комиссией Приморской областной земской управы по обвинению в сотрудничестве с правительством Колчака. В марте 1920 г. последовал арест управляющего Владивостокской таможни И. К. Ковалевского. Конкретные обвинения ни тому, ни другому так и не были предъявлены, и в апреле 1920 г. оба были освобождены. Отвечая на вопросы следственной комиссии, бывший таможенный инспектор П. П. Маевский высказал твердую уверенность в том, что именно конфликт с земской управой летом 1918 г. дал повод считать его противником земства и послужил основанием для ареста и содержания в городской тюрьме весной 1920 г. (РГИА ДВ. Ф. Р-596. Оп. 2. Д. 107. Л. 6 об.).

Дошедшая до нас в документах делопроизводства история развернувшегося летом 1918 г. конфликта позволяет увидеть, что даже в такой сугубо практической сфере, как контроль над ввозом/вывозом грузов, переплелись профессиональные интересы, политические пристрастия и личные амбиции обычных людей, поставленных в необычные обстоятельства.

\section{Литература}

1. Виноградов П.В. Архангельский и Владивостокский порты в годы Первой мировой войны (1914-1917 гг.) // Военно-исторический журнал. 2015. № 3. С. 53-57.

2. Виноградов П.В. Значение Владивостокского порта в стратегических грузоперевозках в годы первой мировой войны (на примере обработки железнодорожных грузов) // История Гражданской войны на Дальнем Востоке и история русской әмиграции: материалы Всероссийской научно-практической конференции, посвященной 100-летию окончания Гражданской войны и интервенции на Дальнем Востоке: Благовещенск, 13 мая 2021 г. / отв. ред. Д.В. Буяров, Д.В. Кузнецов. Благовещенск: Изд-во БГПУ, 2021. С. 42-47.

3. Головин С.А., Виноградов П.В. Торговый порт Владивостока в системе транспортных связей стран Антанты в годы Первой мировой войны // Общество: философия, история, культура. 2018. № 1. 63-67.

4. Иситт Б. Из Виктории во Владивосток: Канадская Сибирская экспедиция:1917-1919 гг. / Пер. с англ. С. Панич. Владивосток: Дальнаука, 2013. 392 с.

5. Лаврик Л.А. Развитие института таможенного представительства в России в годы революции и гражданской войны (на примере Дальневосточного региона) // Таможенная политика России на Дальнем Востоке. 2020. № 3 (92). С. 77-87.

6. Рынков В.М. Источники доходов региональной власти Приморья в феврале 1920 - октябре 1922 г.: опыт реконструкции // Итоги и перспективы развития исторической науки на Дальнем Востоке России (Десятые Крушановские чтения, 2021 г.). Владивосток: Дальнаука, 2021. С. 130-136.

7. Тригуб Г.Я. Местное самоуправление на Дальнем Востоке России в условиях гражданской войны (1918-1920) // Россия и АТР. 2013. № 1(79). С. 18-35.

\section{Транслитерация по ГОСТ 7.79-2000 Система Б}

1. Vinogradov P.V. Arkhangel'skij i Vladivostokskij porty v gody Pervoj mirovoj vojny (1914-1917 gg.) // Voenno-istoricheskij zhurnal. 2015. № 3. S. 53-57.

2. Vinogradov P.V. Znachenie Vladivostokskogo porta v strategicheskikh gruzoperevozkakh v gody pervoj mirovoj vojny (na primere obrabotki zheleznodorozhnykh gruzov) // Istoriya Grazhdanskoj vojny na Dal'nem Vostoke i istoriya russkoj ehmigratsii: materialy. Vserossijskoj nauchno-prakticheskoj konferentsii, posvyashhennoj 100-letiyu okonchaniya Grazhdanskoj vojny i interventsii na Dal'nem Vostoke: Blagoveshhensk, 13 maya 2021 g. / otv. red. D.V. Buyarov, D.V. Kuznetsov. Blagoveshhensk: Izd-vo BGPU, 2021. S. 42-47.

3. Golovin S.A., Vinogradov P.V. Torgovyj port Vladivostoka v sisteme transportnykh svyazej stran Antanty v gody Pervoj mirovoj vojny // Obshhestvo: filosofiya, istoriya, kul'tura. 2018. № 1. 63-67.

4. Isitt B. Iz Viktorii vo Vladivostok: Kanadskaya Sibirskaya ehkspeditsiya:1917-1919 gg. / Per. s angl. S. Panich. Vladivostok: Dal'nauka, 2013. 392 s.

5. Lavrik L.A. Razvitie instituta tamozhennogo predstavitel'stva $\mathrm{v}$ Rossii v gody revolyutsii i grazhdanskoj vojny (na primere Dal'nevostochnogo regiona) // Tamozhennaya politika Rossii na Dal'nem Vostoke. 2020. № 3 (92). S. 77-87. 
6. Rynkov V.M. Istochniki dokhodov regional'noj vlasti Primor'ya v fevrale 1920 oktyabre 1922 g.: opyt rekonstruktsii // Itogi i perspektivy razvitiya istoricheskoj nauki na Dal'nem Vostoke Rossii (Desyatye Krushanovskie chteniya, 2021 g.). Vladivostok: Dal'nauka, 2021. S. 130-136.

7. Trigub G.YA. Mestnoe samoupravlenie na Dal'nem Vostoke Rossii v usloviyakh grazhdanskoj vojny (1918-1920) // Rossiya i ATR. 2013. № 1(79). S. 18-35.

Беляева Н. А. Контроль над грузами во Владивостоке в контексте политической борьбы летом 1918 г.

На основе документов Российского государственного исторического архива Дальнего Востока (РГИА ДВ) рассматривается ситуация, сложившаяся во Владивостоке летом 1918 г. Попытка Приморской областной земской управы взять под контроль использование грузов во Владивостоке в краткий период междувластия (после свержения власти Советов и установления власти Колчака) вылилась в её противостояние с таможней. На основе архивных документов исследуется подоплека конфликта. Он рассматривается как отражение политической борьбы и личного противостояния.

Ключевые слова: Владивосток, политическая борьба, использование грузов, Приморская областная земская управа, таложенный инспектор, таложня

Belyaeva N. A. Control of Cargo Export from Vladivostok in the Political Context in the Summer of 1918.

The situation in Vladivostok in the summer of 1918 is being considered on basis of the documents of the Russian State Historical Archive of the Far East (RGIA DV). The Primorsky Regional Authorities (Zemstvo Council) attempt to take control of the goods in Vladivostok during a short interregnum (after the overthrow of the Soviets and the establishment of Kolchak's power) resulted in their confrontation with the Customs. The archival documents are used to investigate the background of that conflict. It is regarded as a reflection of political struggle and personal confrontation.

Key words: Vladivostok, the use of goods, political struggle, Primorsky regional Zemstvo Council, a customs inspector, Customs

Для цитирования: Беляева Н. А. Контроль над грузами во Владивостоке в контексте политической борьбы летом 1918 г. // Ойкумена. Регионоведческие исследования. 2021. № 4. C. 63-68. DOI: $10.24866 / 1998-6785 / 2021-4 / 63-68$

For citation: Belyaeva N. A. Control of Cargo Export from Vladivostok in the Political Context in the Summer of 1918. // Ojkumena. Regional researches. 2021. № 4. P. 63-68. DOI: $10.24866 / 1998-6785 / 2021-4 / 63-68$ 